Copyright (C) 2017 by Academic Publishing House Researcher

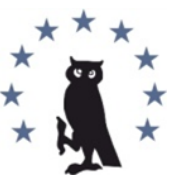

Published in the Russian Federation

European Researcher. Series A

Has been issued since 2010.

ISSN 2219-8229

E-ISSN 2224-0136

2017, 8(3): 256-267

DOI: $10.13187 /$ er.2017.3.256

www.erjournal.ru

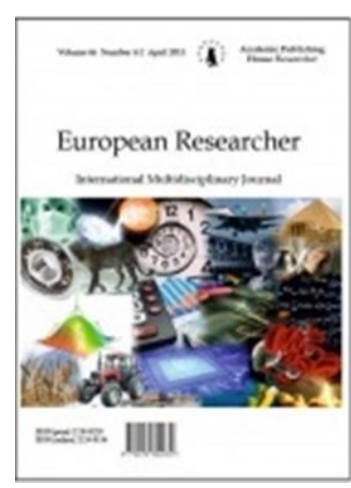

UDC 299.51

\title{
Interaction of 'Greater' and 'Minor' Cultures in Late Imperial China: Case of Popular Woodblock Prints Nianhua from the V. Alekseev's Collection
}

\author{
Ekaterina A. Zavidovskaya ${ }^{a,}$, Ekaterina A. Teryukova ${ }^{\mathrm{b}}$ \\ a National Tsing Hua University, Taiwan \\ b The State Museum of the History of Religion, Russian Federation
}

\section{Abstract}

The paper examines explanatory notes written by the Chinese mentors (xiansheng 先生) for the popular prints nianhua年畫collected by the Russian sinologist Vasily Alexeev (1881-1951) during his studies in China in 1906-1909. The studied portion of the noted is stored in the archives of the State Museum of History of Religion (Saint-Petersburg). These commentators possess higher or lower level of learning in Confucian classics and traditional literature; some of them are industry insiders with good knowledge of pictures' meanings. The paper views their notes as a representation of 'the greater culture' evaluation or commenting on 'the minor culture' of the popular prints. Closer reading of the mentors' notes reveals their intention to show off rudimentary knowledge of the classics, which is not always relevant to the content or questions raised by V. Alekseev.

Keywords: elite and popular culture, imperial China, Vasiliǐ Alekseev, woodblock prints, classical canons.

\section{Introduction}

A discussion on cultural integration in the late imperial China took place in Western academia in 1980-s. It was probably spurred by earlier anthropological studies outside China, which tended to perceive traditional societies and communities as isolated entities. For instance, Robert Redfield (1897-1958) studied Mexican communities and introduced a theory of 'little and great traditions'. He was followed by anthropologists M. Singer and M. Marriott who conducted research in Indian villages in the 1960-s, and further elaborated the theory of 'great' and 'little' traditions. According to it, peasants and the illiterate stratum follow 'the little tradition', literate elites follow 'the great tradition' (Marriott, 1955; Singer, 1972). The volume "Popular Culture in Late Imperial China" raises the question about the degree to which Ming and Ch 'ing citizens shared ideas, values, assumptions' and came to conclusion that 'cultural integration was a particular feature in China backed by educational syllabuses, and pressures of local elites that ensured conformity' (Johnson et al., 1985: 130). The authors of the volume also argued that China had a much higher degree of cultural integration than France in the imperial period due to 'a much greater diffusion of literacy skills through various social groups in China' (Johnson et al., 1985:

\footnotetext{
${ }^{*}$ Corresponding author

E-mail addresses: katushaza@yahoo.com (E.A. Zavidovskaya), eaterioukova@mail.ru (E.A. Teryukova)
} 
403). J. Lust mentions in his study of the popular prints, 'as for popular culture, it enjoyed a certain independence of its own within the sphere of the national... there were the censorships and the elite values, the conformities whereby printmakers would know what could be placed in the public eye' (Lust, 1996: 130). Recently historians and anthropologists doing research on China have initiated a new discussion of the arguments laid by James Watson about the importance of 'orthopraxy' (correct practice, rightness of practice) as a factor integrating elite and popular culture. Watson argues that 'the construction of a unified culture in China depended primarily on nurturing and maintaining a system of shared rites' rather than on shared beliefs or orthodoxy (Watson, 1993: 84). According to Michael Szonyi, 'James Watson's arguments about standardization and orthopraxy have proved very fruitful in exploring important questions in the history of late imperial China. According to Watson, this influence contributed to the high degree of cultural integration across classes and regions that characterized late imperial China' (Szonyi, 2007: 47-8). Watson explicitly linked this theory of standardization with his theory on orthopraxy. Having studied popular cults and ancestral sacrifice in the same area as Watson did, Michael Szonyi concludes that 'claims about standardization and adherence to orthopraxy should be distinguished from substantive standardization and adherence to orthopraxy ....and that this distinction has some significant implications for the theories' capacity to explain social and cultural integration in the Chinese history' (Szonyi, 2007: 4). These debates affirmed the uniformity of elite and popular cultures in China, and focused on 'how' and 'by what means' this effect was achieved. Recent debates do not question the unity of the 'grand' and 'small' cultures, or 'elite' vs. 'popular, mass' culture in traditional China, but rather pose questions on interaction between cultural norms propagated from the imperial centre and local cultures, thus questioning the interaction between 'national' and 'local'.

Long before these debates Russian sinologist Vasiliǐ Alekseev (1881-1951) emphasized the value of popular prints nianhua 年畫, which encompass elements of both elite culture and that of illiterate masses. He made acute observation that these prints have intricately preserved ancient culture, history, literature, legends, which were transformed into a form easily intelligible for simple people. Even though small proportion of the elite culture trickled to the grass root level; yet these elements maintained the core of collective anonymous creativity, and their study presents more challenge than things prone to quick changes under influence of fashion (Alekseev, 1958: 65). Alekseev's interest in popular prints and religion supplanted his in-depth studies of the Chinese classics and poetry, laying ground to a systematic and wholesome approach to the Chinese culture characteristic of the Russian sinological school. This method suggested not limiting oneself to the classics and elite culture, but including prints, temple epigraphy, theatre into the scope of materials. This paper is to analyze a number of hand-written notes stored in the Museum of the History of Religion (Saint-Petersburg), which illustrate how 'coarse pictures' were perceived and evaluated by Alekseev`s mentors as bearers of the traditional learning.

\section{Materials and methods}

When did Vasiliǐ Alekseev obtain a large collection of popular woodblock prints nianhua and explanatory notes for them? He took deep interest in amulets long before coming to China. In 1902, he was assigned to systematize and describe a collection of Chinese coins from the Hermitage Museum, among which he discovered some coin shaped amulets. Later Alekseev studied collections of coins and protective amulets in London and Paris. The London 's collection of amulets was richer than the one in Paris, Alekseev checked it twice and drew sketches of these images. His interest in Chinese folklore sprang from this study. The seminal goals of his stay in China were to write a master dissertation on popular culture, supplement his existent collection of amulets and obtain reliable explanations of their meaning. These topics were quite revolutionary for the times when 'sinology' suggested studies of the classical canons and historical writings. Russian scholar tended to focus on those aspects of culture which were overlooked by Confucian scholars. Having arrived in China, Alekseev embarked on materials which surrounded him everywhere, he copied shop signs and various inscriptions that covered almost all the surfaces and took up purchasing the woodblock prints, since he found their motifs to be quite close to those of the amulets. Alekseev first saw popular prints exhibited in Saint-Petersburg by botanist Vladimir Komarov (1869-1945) who collected them during his expedition to Manchuria in 1896. The owner 
presented Alekseev with one picture, and a young sinologist hopelessly tried to decipher its puzzles during his student years.

A diary note dated October 1, 1907, indicates that Alekseev collected seventy pieces of small size prints in Beijing and two hundred large size pieces in Tianjin. He handed them over to his language teacher Meng Xijue*, who assisted with their interpretation. Notes written by Meng and other teachers were bound together into six booklets with the title written in Chinese Cuhua jieshuo 粗畫解 說 (Explanations of the coarse pictures). It contains explanatory notes for 433 pictures (the notes have numbers on them and correspond with numbers written on the nianhua prints). This document is kept in the State Hermitage Museum and remains understudied. In 1955-1956 Alekseev`s widow donated approximately two thousand sheets of woodblock prints to the State Hermitage, they have been fairly well studied and exhibited in Russia and abroad (Rudova, 1960; Rudova, 1961; Rudova, 1988; Pchelin, Rudova, 2008; Zang, 1995). The curator of the Hermitage collection Maria Rudova referred to these notes when compiling nianhua catalogues (Rudova, 2003). Charging from Alekseev`s diary, we assume that this set of notes explained the scope of pictures obtained by Alekseev before his expedition around North China with French sinologist and historian Édouard Chavannes (1865-1918) in May-December, 1907 (Riftin, 2009: 451).

The route of Chavannes`s expedition was the following: Beijing 北京 - Tianjin 天津 - Dezhou 德州 - Yangliuqing楊柳青 - Taianfu 泰安府 - Jinanfu濟南府 - Qufu 曲阜 - Zouxian鄒縣- Jiningfu 濟寧府 - Kaifeng開封 - Sishuixian汜水縣 - Zhuxianzhen朱仙鎮 - Zhengzhou鄭州 - Dengfengxian 登封縣- Luoyang 洛陽 - Longmen龍門 - Lingbaoxian靈寶縣 - Xi anfu 西安府 - Qianzhou乾州Weinanxian 渭南縣 - Taiyuanfu 太原府 - Zhangjiakou 張家口- Huaian 懷安-Beijing北京. Alekseev purchased woodblock prints in Yangjiuqing 楊柳青, Taian 泰安, Qufu曲阜, Kaifeng 開封, Zhuxianzhen朱仙鎮, Dengxian登封縣, Lingbaoxian靈寶縣, Xi`an 西安, Weinanxian渭南縣, Taiyuan太原. Upon Alekseev`s return to Beijing much help with writing comments for the prints came from the professional nianhua painter Zhang Haoru ${ }^{\dagger}$. In his diary dated January, February and March 1908, Alekseev mentions that Mr. Zhang Binghan wrote notes for prints numbered from 434 to 815, they were purchased during the expedition and in Beijing and included pictures with Door Gods menshen門神and 'hundred-gods' baifen er百份兒 (Riftin, 2009: 458). Alekseev was not fully satisfied with the Zhang `s work, he appreciated Meng Xijue much more (Riftin, 2009: 458). In the beginning of 1909, Alekseev used his vacation to travel and purchase woodblock prints in Shanghai, Hangzhou, Suzhou and Hankou. As Alekseev`s daughter Marianna Bankovskaya mentions in her book, he worked out a list of 282 topics based on this expedition with Chavannes that needed further study and systematization, many of them were relevant to popular prints (Bankovskaya, 2010: 444).

Boris Riftin mentions total of 1452 sheets of hand-written notes, apart from the abovementioned Hermitage booklet; another portion is housed at the Archive of the Russian Academy of Sciences, Saint-Petersburg brunch. The title of the archive entry is "Description of the Chinese popular prints featuring the works of Chinese literature. Notes of xiansheng with remarks by Alekseev. In Chinese". This portion contains descriptions for 470 pieces of popular prints from Alekseev`s collection. They are dated 1906-1907. Riftin discussed some of these notes in his Chinese language article for the volume introducing Russian collections of nianhua, up to present there is no catalogue or a thorough study of these notes (Riftin, 2009: 458-61). What presents the main challenge is that these notes are kept separately from the pictures. Without doubt, they represent a unique case of written communication between people of two different cultures. It is a rare case of the documented interaction between a sinologist and his informants.

This paper addresses yet another scope of the notes made by xiansheng and Alekseev during his trips to China. They are resided in the Research and Historical Archive of the State Museum of

\footnotetext{
${ }^{*}$ Meng Xijue 孟錫玨 (1870-1938), second name zi Yushuang 玉雙, from Wanping county 宛平縣, Tianshun prefecture順天府, north-east of Beijing, received jinshi degree in 1898. Before the establishment of the Republic in 1912 he occupied posts of an editor at Hanlin academy, a record keeper at the governor-general office of Jiangbei 江北 (present day Chongqing 重慶), a record keeper of Tianjin Pukou railroad 津浦鐵路 etc. ${ }^{\dagger}$ Zhang Haoru 章浩如 (1870 - ?), second name zi Binghan 炳漢, or Weihan 維漢. He was a painter at a shop producing prints specializing on landscapes and human figures.
} 
the History of Religion (Saint-Petersburg), their study and matching with nianhua pictures is one of the goals of the joint Russian-Taiwanese project supported by the governmental funds of the two countries (2015-2017). Russian scholars who studied Alekseev`s materials on popular prints were aware of these notes, some of them were consulted by his students who edited posthumous publication of their teacher's expedition diary (Alekseev, 1958). At the moment fourteen folders marked with the letter Д (delo case) containing total of 41 envelopes are registered as 'Alekseev`s fund'. They feature xiansheng 's comments on popular prints, temple and street epigraphy, folklore and diary notes in Russian and Chinese. Staff personnel of the museum supposes that these notes entered the Museum 's archive around 1950-s, and no one studied them since then. In 1938, Academician Alekseev was invited to work as a curator of an exhibition 'Religions in China', during the same year the museum purchased a collection of about 1000 pieces of woodblock prints from him. Alekseev selected exhibit items (mainly woodblock prints and photographs), proposed a plan of the exhibition and provided the exhibits with museum labels and commentaries. Probably the breaking out of the war in June, 1941, hindered this venture.

As for methodology, this study followed a principle of scientific objectivity while applying content analysis of the studied documents and comparative analysis of hand-written and pictorial sources from the funds of the State Museum of History of Religions, which brought the authors to a new level of generalizations and allowed them to introduce completely new and unstudied materials on Chinese popular arts and religions to the scholarly community.

\section{Discussion}

The characteristic feature of the traditional education in East Asia has been its cohesion with religion (Tibet, Mongolia) or state examination system for official posts (China, Korea, Vietnam), therefore, a person became literate as a result of learning the Confucian canon or Buddhist scriptures. The standard curriculum suggested memorizing a set of books, the level of understanding of these maxims varied among the individuals and determined whether a person was capable of participating in examinations or not. Similarly, Alekseev`s mentors possessed different level of education, e.g. Meng Xijue even received the highest jinshi 進士 degree and occupied official posts. Status of a 'master' xiansheng means that they were teaching reading and writing skills, further study is required to find out whether they had passed the initial exam for xiucai 秀才 degree. Alekseev also consulted artists who produced woodblock designs and were 'half literate"*. We believe that finding out more details about the authors of the notes helps to determine the level of their expertise in popular prints, which were generally despised by the men of letters ${ }^{\dagger}$. Importantly, the notes were compiled not only by teachers, but by artisans too.

After visiting woodblock prints production centre in Zhuxianzhen of Henan province and talking to a painter in one of the shops Alekseev made a very accurate observation of their role in the production of the crafts representing 'minor' popular culture: 'I saw these half-literate people..., they are neither workers, nor scholars... They are the bearers of folk traditions and keepers of the Confucian traditions...This ambivalent nature of author-painters adds complexity to the pattern of popular prints which adopts plots borrowed from a thick cultural layer and inherits a long-standing tradition' (Alekseev, 1958: 176). This observation grasps the essence of the print painters' role of a bridge between the high-brow Confucian canon and illiterate consumers of the prints. John Lust adds that these artisans 'were of peasant origins with a leavening of graduates of preliminary examinations, former school teachers, etc., or with a few years in a local school before being called on to support the family' (Lust, 1996: 134). He outlines their major duties in the shop: 'the master supplied an uncolored draft which was expected to be impeccable, hung up for discussion with by the team on its quality, its likely impact and reception by the public' (Lust, 1996: 148). Artisans were the insiders of the industry and could provide many unique details, but, as will be shown below, their ability for interpretation could in some cases be hampering.

\footnotetext{
* In her study of the late Qing education Evelin Rawski also applies the term 'semiliterate' attributed to those who could not read or write beyond the elementary level (Rawski, 1979: 3).

+ The problem of the prints' misinterpretations offered by this group of consultants is discussed in (Yang, 2013).
} 
Below we will address explanatory notes by two different commentators, discuss their approach to the images and their answers to the questions written by Alekseev in Chinese. The folder marked as 'Д 6' holds an envelope titled “№ 20 Album門神” (menshen Door gods), below there is an addition “+ 送子娘” (songzi niang Child giving mother goddess). Total of 64 notes offering explanations for 64 prints were made by the same person, the level of calligraphy is of a satisfactory level, in rare cases there are misspellings when some character is erroneously replaced by its homonym. The majority of the notes describes the coupled pictures of Door gods which are hung on the door leafs, there are also several pictures featuring Child giving goddess and Celestial official tianguan 天官, or Door god for a single-winged door. Almost all the notes follow the same pattern and describe the attire of the gods, weapons, objects on their waist and hands, objects and slogans around the main figure. The typical description is provided below. The original punctuation of the texts is preserved:

\begin{tabular}{|c|c|}
\hline $\begin{array}{l}\text { 門四三 } \\
\text { menshen san } \\
\text { 此畫五代時李存孝收伏高思繼也 二人各 } \\
\text { 手使抓皆穿鎧甲 仍作上下二聯 此二生前勇 } \\
\text { 力過人 李存孝有打虎之事 故亦可避邪魅也 } \\
\text { ci hua wu dais hi li cun xiao shou fu gao } \\
\text { si ji ye err en ge shou shi zhua jie chuan kaijia } \\
\text { reng zuo shang xia er lian ci err en sheng qian } \\
\text { yong li guo ren li cun xiao you da hu zhi shi gu } \\
\text { yi ke bi xie mei ye } \\
\text { Question written by Alekseev: 誰打誰未 } \\
\text { 詳 } \\
\text { shei da shei wei xiang } \\
\text { Answer: 李存孝打倒高思繼後收伏為俘耳 } \\
\text { li cun xiao da dao gao si ji hou shou fu } \\
\text { wei fu er }\end{array}$ & $\begin{array}{l}\text { Door [God] } 43 \\
\text { In this picture [is shown how] Li Cunxiao } \\
\text { of the Five Dynasties [period] subdued Gao Siji } \\
\text { They seize each other with their hands both are } \\
\text { wearing armor these [pictures] are the upper } \\
\text { and lower in a pair these two people were the } \\
\text { boldest of the bold during their lifetime there is } \\
\text { a saying about Li Cunxiao that he had killed a } \\
\text { tiger for this reason [this picture] expels evil } \\
\text { charms } \\
\text { Question written by Alekseev: it is not } \\
\text { clarified who subdued whom } \\
\text { Answer: Li Cunxiao subdued Gao Sijin and } \\
\text { took him as a captive }\end{array}$ \\
\hline
\end{tabular}

This note suggests that the reader knows the story of the Five Dynasties and Ten states period wudai shiguo 五代十國 (907-979) and biographies of two warriors Li Cunxiao李存孝 (?-894, late Tang dynasty) and Gao Siji 高思繼. The biography of Li Cunxiao was included into the 'Old and New histories of the Five dynasties' (jiu wudaishi舊五代史, xin wudaishi新五代史). But xiansheng probably refers to the deeds of this hero mentioned in the popular historical novel 'Romance about the destruction of Tang and history of Five dynasties' (Can tang wudaishi yanyi 殘唐五代史演義) complied by the Ming dynasty author who used materials from the official chronicles the 'Book of Tang' (Tang shu唐書), the 'Histories of Five Dynasties" and popular legends. It depicts the fall of the Tang dynasty and warfare that followed it. Alekseev`s question reveals that he was not familiar with these two generals and the story of their struggle.

Below there is another note explaining a coupled picture of Door gods, it is an interesting case when the Alekseev`s logic made him wonder about the use and appearance of some parts of the armor, and xiansheng gives a curious answer:

\begin{tabular}{|c|c|}
\hline $\begin{array}{l}\text { 門七八 } \\
\text { men qi ba } \\
\text { 此亦門神也 周身穿著盔甲 背有護脖旗腰 } \\
\text { 跨箭袋內盛羽翎箭手挐金瓜錘作左右二式也 } \\
\text { ci yi menshen ye zhou shen chuan zhe kui } \\
\text { jia bei you hu bo qi yao kua jian dai nei sheng } \\
\text { yu ling jian shou na jin gua chui zuo you er shi } \\
\text { ye }\end{array}$ & $\begin{array}{l}\text { These are the Door gods too Each wears } \\
\text { a full suit of armor on the back [there is] a flag } \\
\text { protecting the neck across the waist there } \\
\text { hangs a cocker full of feathered arrows a } \\
\text { jinguachui in his hand two pictures make a } \\
\text { pair }\end{array}$ \\
\hline
\end{tabular}




\begin{tabular}{|c|c|}
\hline $\begin{array}{l}\text { Alekseev`s question written in pencil: 旗 } \\
\text { 乃易破之物何能護脖耳 } \\
\text { qi nai yi po zhi wu he neng hu bo er } \\
\text { (a part of this question is covered by the } \\
\text { written answer) } \\
\text { Answer: 旗雖易破。然護脖者。不在旗而 } \\
\text { 在旗的鐵桿也。原為有人在背後。用長鎗刺 } \\
\text { 脖。有此旗桿。略一轉動。自將他人之槍擱住 } \\
\text { 或撥開也。旗為 好看。係余事耳。凡為元帥 } \\
\text { 者。皆有令旗也 } \\
\text { qi sui yi po. ran hu bo zhe. bu zai qi er zai } \\
\text { qi de tiegan ye. yuan wei you ren zai bei hou. } \\
\text { yong chang qiang ci bo. you ci qi gan, lüe yi } \\
\text { zhuan dong. zi jiang tar en zhi qiang ge zhu huo } \\
\text { bo kai ye. qi wei hao kan. xi yu shi er. fan wei } \\
\text { yuan shuai zhe. jie you jing qi ye }\end{array}$ & $\begin{array}{l}\text { Answer: even though the flag can be } \\
\text { easily torn, yet it can protect the neck. It is not } \\
\text { a cloth, but a metal flagpole. In the past it } \\
\text { could happen that [someone] used a long spear } \\
\text { to pierce the neck. [If] there is this flagpole. } \\
\text { A small twist. The spear of another man is } \\
\text { caught and poked away. The flag cloth looks } \\
\text { good. It is an excessive thing. Every } \\
\text { commander-in-chief. Has this command flag. }\end{array}$ \\
\hline
\end{tabular}

Jinguachui 金瓜鍾 is a cold weapon with a pike in the shape of a gold gourd. Alekseev was perplexed how a soft-flag cloth could protect the neck of a warrior. The phrase in Chinese does not give a clue, in order to understand it, one should at least be familiar with the scenic costume of an actor performing a warrior in a traditional drama, and the flags behind their back also signify the number of armies or regiments under their command. So, Alekseev raised this question to enhance his cultural competence.

A considerable number of the notes describes the weapons of the Door gods. Alekseev asks questions about their meanings, e.g. the original text says: “上聯門神盔甲穿龍袍身背護脖旗手托竹 節鋼鞭' (shang lian men shen kui jia chuan long pao bei hu bo qi shou tuo zhu jie gang bian. The Door god from the upper picture wears a full imperial robe on top of the armor, a flag is protecting his neck, in his palm he holds zhujie gangbian), Alekseev underlined the four characters with a pencil and asked what this thing was. His mentor wrote an answer: “武將上陣的兵器王靈官 亦挐鞭與此皆為驅邪耳' (wu jiang shang zhen de bing qi wang ling guan yin a bian yu ci jie wei qu xie er. This is a weapon which a general uses during warfare, the Celestial official Wang holds a whip and this thing in order to expel noxious forces) (note門 二十二三 men er shi er san 'Door 2223'). Zhujie gangbian竹節鋼鞭 is a cold weapon in the shape of bamboo sections, an attribute of the Door god called Jing De 敬德.

After several months of studying popular prints Alekseev had gained much knowledge and could express doubts about explanations of the xiansheng, as seen in the description below:

\section{門五十四 五十五}

men wu shi si wu shi wu

此幅門神頭帶鳥紗帽身穿蟒袍橫玉帶一手 挐牙笏一手托盤內有三足爵一只如意一個為進 爵如意旁立一童手掌旗傘上聯面前立仙鶴下聯 立一鹿口中各啣芝草也

ci fu men shen tou dai wu sha mao shen chuan mang pao heng yu dai yi shou na ya cong yi shou tuo pan nei you san zu jue yi zhi ru yi yi ge wei jin jue ru yi pang li yi tong shou zhang qi san shang lian mian qian li xian he xia lian li yi lu kou zhong ge xian zhi cao ye

Alekseev's question: 此類之像非門神也 非武將也然而何名之神且和實門神何有人供

ci lei zhi xiang fei men shen ye fei wu

\section{Door [God] 54-55}

The Door god on this picture wears an official's hat with wings, a full robe with a dragon ornament and jade belt, in one hand he holds an ivory tablet, in another hand he holds a tray, on which lie a tripod and ruyi verge. This means 'would you receive a title of a duke upon your wish'. A young servant stands beside, he holds a decorated umbrella, on the upper picture in front of them stands a crane, in the corner of the lower picture there is a deer, they hold a fungus in their beak and jars.

Alekseev's question: this is not a picture of a Door god, it is not a warrior, what is the 


\begin{tabular}{|c|c|}
\hline $\begin{array}{l}\text { jiang ye ran er he ming zhi shen qie he shi men } \\
\text { shen he you ren gong } \\
\text { Answer: 此類門神。與第六十六頁之取吉 } \\
\text { 利之意相同。非為避邪也 } \\
\text { ci lei men shen. yu di liu shi liu ye qu ji li } \\
\text { zhi yi xiang tong. fei wei bi xie ye }\end{array}$ & $\begin{array}{l}\text { Answer: this is a type of a Door god } \\
\text { picture, [it has] the same auspicious meaning } \\
\text { as the picture No. } 66 \text {. It has no meaning of } \\
\text { expelling evil forces }\end{array}$ \\
\hline
\end{tabular}

Therefore, the author of this set of sixty four notes rarely supplements his comments with references or quotations from the classics or literary pieces; he limits himself to the description of the objects and their meaning what requires competence in the popular culture rather than Confucian classics. Yet the note listed below reveals his literacy in Daoist scriptures and poetry.

\begin{tabular}{|c|c|}
\hline 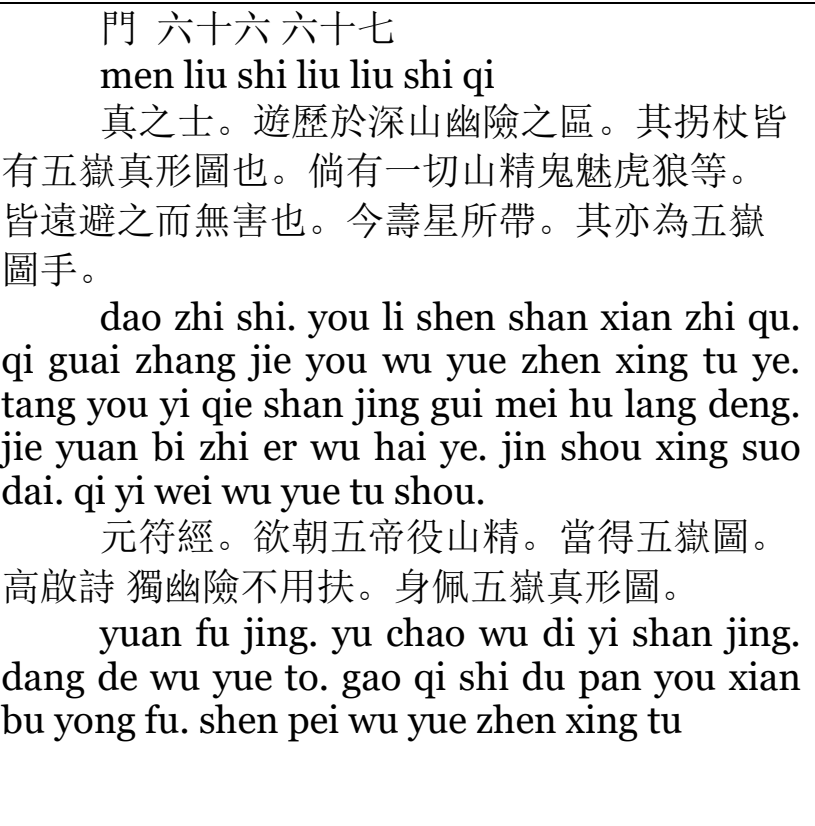 & $\begin{array}{l}\text { A Daoist. Travelled in deep mountains } \\
\text { and hard-to-reach areas. On his crutch there } \\
\text { [hangs] a Map of the genuine shape of the Five } \\
\text { peaks. Should mountain demons, ghosts, } \\
\text { tigers, wolves and others appear. They keep } \\
\text { away and do no harm. The God of Longevity } \\
\text { Shouxing also carries [it]. It is also the Map of } \\
\text { the Five peaks. } \\
\text { Scripture of the Primordial talisman. } \\
\text { [someone] wished to pay a visit to the Five } \\
\text { emperors, had to fight with mountain demons, } \\
\text { obtained the Map of the Five peaks. Poem of } \\
\text { Gao Qi 'alone ascend dangerous peaks, no need } \\
\text { to lean on [one`s] hand. Carry the Map of the }\end{array}$ \\
\hline
\end{tabular}

We suppose that the author of the commentary probably wanted to quote the 'Upper Scripture of Begetting Five Talismans of the Genuine Unity of the Superior and Boundless Great Dao’ (Taishang wuji dadao ziran zhen yiwu cheng fu shang jing 太上無極大道自然真一五稱符上經), better known by its short title 'Upper Scripture of Begetting Five Talismans' (wu chengfu shang jing 五稱符上經). It is included in the collection of the early Daoist documents 'The Seven Tablets in a Cloudy Satchel' (Yunqi qiquan雲芨七簽, scroll 81, second part of the section 'talismans and maps' futubu er 符圖部二, compiled circa. 1017-1021 by Zhang Junfang 張君房). This scripture has a saying: 'The teacher/sage wished to establish the Five emperors, had a fight with mountain demons, obtained the Map of the Five peaks then' (zi yu ding wudi, yi shanjing, dangde wuyuetu 子 欲定五帝, 役山精, 當得五获圖). So xiansheng did not name the scripture and quoted it correctly. He also quoted a poem 'Dongting mountain' (dongting shan洞庭山) by Yuan dynasty poet Gao Qi (高啟1336 - 1374). What is the use of these two quotations? They seem to just have come into his mind as something relevant to the words 'the Map of the Five peaks', here a type of associational thinking is seen.

Commentary for another set of pictures was written by another Chinese consultant, supposedly, Tian Ziru田子如. The calligraphy of these notes is coarser then the previous set, misspellings occur more often and many characters are written in the simplified form which points at lower educational level of the person who wrote them. This set contains in total 109 pieces of notes and a conclusion (zonglun 總論) with continuing numbering of pages, the name of the commentator Tian Ziru is placed at the end of the Conclusion. This set of notes mostly describes the Door gods and the God of wealth caishen財神. Importantly, the very approach is different from 
the previous set of notes: the author rarely describes all the objects on the picture, he puts stress on the auspicious symbols and provides explanation of their meanings, since these meanings or wishes are mainly not expressed verbally, but via the objects in the picture, their names sound close to the sound of auspicious words (e.g. picture of a bat fu 蝠expresses wish of happiness fu 福).

The way Tian Ziru wrote his notes reveal that he was rather familiar with the woodblock printing industry, because he provided specific terms used for different compositions of gods and their nicknames in the North and South of China. The notes also tell how to properly hang the pictures - on the outside or inner doors, double/single-leaf doors. The typical description is below:

\begin{tabular}{|c|c|}
\hline $\begin{array}{l}\text { 十六頁 } \\
\text { shi liu ye } \\
\text { 此亦福祿壽之像也南方人多用之呼之謂淨 } \\
\text { 面三星 於北方不大相宜土人名為素片子言其不 } \\
\text { 甚華麗也故多有作俗畫用者 } \\
\text { ci yi fu lu shou zhi xiang ye nan fang ren } \\
\text { duo yong zhi hu zhi wei jing mian san xing yu } \\
\text { bei fang bud a xiang yi tu ren ming wei su pian } \\
\text { zi yan qi bu shen hua li ye gu duo you zuo su } \\
\text { hua yong zhe }\end{array}$ & $\begin{array}{l}\text { Page } 16 \\
\text { This also is an image of [three deities of] } \\
\text { Happiness, Official's salary, Longevity the } \\
\text { southerners often use it and call it the 'three } \\
\text { stars with clean [not painted] faces' for the } \\
\text { northerners it is not appropriate to use names } \\
\text { for the clay made figures, they are called } \\
\text { 'plain/white plates' which means 'not } \\
\text { gorgeous', the reason is that they are often } \\
\text { [drawn] on coarse pictures }\end{array}$ \\
\hline
\end{tabular}

The author mentions specific terms used for this particular type of print depicting three deities, which imply connections between the appearance of these deities on woodblock prints and make-up of a Chinese drama actor, since the term 'clean/white face' is used for the theatrical type without a make-up. E.g. iconography of the two most popular Door gods Qin Qiong 秦瓊and Jing De敬德 suggests that they have respectively 'white face' and 'painted face'.

Below is an illustration of a conflict between the Alekseev's logic and his informant's one:

\begin{tabular}{|c|c|}
\hline $\begin{array}{l}\text { 伍頁 } \\
\text { wu ye } \\
\text { 此乃單扇門之門神也又呼之謂小二財因下 } \\
\text { 有招財童子也吉語謂之招財入門借財神門神之 } \\
\text { 音也 } \\
\text { ci nai dan shan men zhi men shen ye you } \\
\text { hu zhi wei xiao er cai xia you zhao cai tong zi ye } \\
\text { ji yu wei zhi zhao cai ru men jie cai shen men } \\
\text { shen zhi yin ye } \\
\text { Remark with pencil: 此童子有䰅 } \\
\text { ci tong zi you xu } \\
\text { 不可泥意此言童子即利市仙官職亦在聚寶 } \\
\text { 童子班也若為之老童恐來入洪門者不欲聲可令 } \\
\text { 一笑 } \\
\text { bu ke ni yi ci yan tong zi ji li shi xian guan } \\
\text { zhi yi zai ju bao tong zi ban ye ruo wei zhi lao } \\
\text { tong kong lair u hong men zhe buy yu sheng ke } \\
\text { ling yi xiao }\end{array}$ & $\begin{array}{l}\text { Page } 5 \\
\text { This Door god is for a single-leaf door he } \\
\text { is also called Little Second rich man (xiao er } \\
\text { cai) because at the bottom there is a Boy } \\
\text { attracting wealth, the auspicious saying is: } \\
\text { 'attract the wealth to enter the gates of the } \\
\text { house', the sound of the word shen from the } \\
\text { Door god menshen is borrowed } \\
\text { Remark with pencil: this boy has a beard } \\
\text { Better not to limit oneself with such a } \\
\text { definition, he is called a 'boy', but his official } \\
\text { post is the Immortal official giving profit in } \\
\text { trade, [he is] also from the group of boys } \\
\text { collecting treasures, [if we speak of] a boy } \\
\text { looking like an old man only those who entered } \\
\text { the society of Hongmen would find it hilarious }\end{array}$ \\
\hline
\end{tabular}

The logic of the xiansheng `s answer is rather curious, he does not perceive the image of a boy collecting treasures in the same way as Alekseev does, and yet he just insists on his own explanation. In the final phrase he makes a joke saying that all common people would not find such an old man boy weird, except for those who 'entered the society of Hongmen' 入洪門, is a term for secret societies or some illegal groups in late imperial China. The commentator probably uses this term in a pejorative sense to delineate those who went astray from common ways. 
The author of this portion of the notes likes to display literacy in the Four books and Five canons (sishu wujing 四書五經), below is a descriptive note mentioning the Analects (Lunyu 論語) attributed to Confucius:

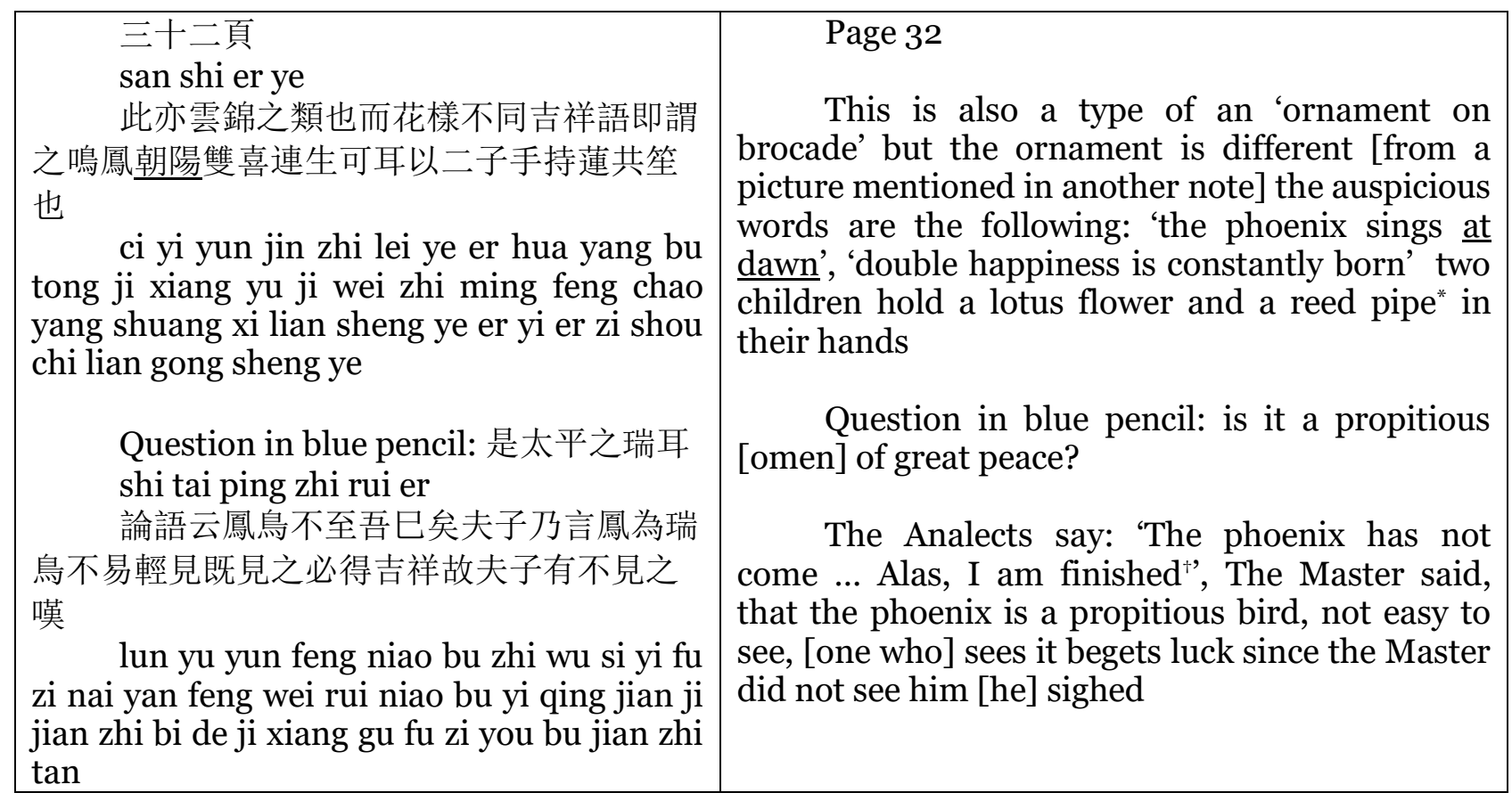

The xiansheng uses the term yunjin 雲錦 ('ornament on brocade') for a certain composition of the woodblock print, which probably uses a contour with a cloud-like ornament. The auspicious phrase used to explain the picture 'phoenix sings at dawn' is also an allusion of a noble man coming to an audience of a wise ruler, the words chaoyang 朝陽 'at dawn' were underlined by Alekseev ${ }^{\ddagger}$, he wanted to know their meaning. I suppose xiansheng misunderstood his question and referred to the 'phoenix'. Does this context really require quoting from the Analects? The commentator recalled a fragment from the classic relevant to the word 'phoenix'. The final comment is just an answer to the Alekseev`s misunderstood question, it is not relevant to the description of the print per se. Below is a pair of prints commented with reference to the Book of Songs (Shijing 詩經):

\footnotetext{
*A lotus flower lian 蓮and reed pipe sheng 笙are homonyms of liansheng 連生 'constantly born'.

${ }^{+}$In the original text this phrase is the following: 子日 : 鳳鳥不至、河不出圖、吾已矣乎 zi yue: feng niao bu zhi,he bu chu tu, wu yi yi hu. 'The Master said: "The Phoenix has not come, the Yellow River has not produced at diagram. Alas, I am finished”' (Chapter: Zihan子军).

${ }^{*}$ Yang Yujun suggests that Alekeev meant the dynasty title Taiping 太平 during the Three kingdom period (256-258) (personal communication, June, 2015).
} 


\begin{tabular}{|c|c|}
\hline $\begin{array}{l}\text { 四十四頁 } \\
\text { si shi si ye } \\
\text { 此亦雙扇門所宜帖者也南方人名為對娃 } \\
\text { 娃取二子雙生之意也吉語可云麟趾公姓 }{ }^{*} \text { 詩經 } \\
\text { 周南 富貴得子或云貴子雙生亦可 } \\
\text { ci ye shuang shan men suo yi tie zhe } \\
\text { nan fang ren ming wei dui wa wa qu er zi } \\
\text { shuang sheng zhi yi ye ji yu ke yun lin zhi } \\
\text { gong xing shi jing zhou nan fe gui de zi huo } \\
\text { yun gui zi shuang sheng yi ke }\end{array}$ & $\begin{array}{l}\text { Page } 44 \\
\text { This picture is suitable to be glued on a } \\
\text { double-leaf door the southerners call it 'a pair of } \\
\text { babies' pointing at the meaning 'two sons are } \\
\text { born in pair', the auspicious phrase can also be: } \\
\text { 'a hoof of the kylin duke`s surname' The Book } \\
\text { of Songs, Songs of Zhou and the South } \\
\text { 'Happiness, nobility, will beget a son', or one can } \\
\text { say: 'precious sons are born in pair' }\end{array}$ \\
\hline $\begin{array}{l}\text { 四十五 } \\
\text { si shi wu } \\
\text { 此頁與四十四同對少婦屋內用之最宜取 } \\
\text { 其有送子之慶也吉語亦周南之什麟定公族貴子 } \\
\text { 連生也可矣俗人即謂之麟送雙子而已 } \\
\text { ci ye yu sis hi si tong dui shao fu wu nei } \\
\text { yong zui yi qu qi you song zi zhi qing ye ji yu } \\
\text { yi zhou nan zhi shen lin ding gong zu gui zi } \\
\text { lian sheng ye ke yi su ren ji wei zhi lin song } \\
\text { shuang zi er yi }\end{array}$ & $\begin{array}{l}\text { Page } 45 \\
\text { This picture is in pair with the page } 44 \text { it is } \\
\text { better to be glued in the room of a newlywed } \\
\text { wife its meaning is to beget a son As auspicious } \\
\text { words [one] can use some phrase from The } \\
\text { Songs of Zhou and the South 'the forehead of the } \\
\text { kylin the lineage of a duke', 'precious sons are } \\
\text { born one after another', common folks also call } \\
\text { it 'the kylin brings a pair of sons' }\end{array}$ \\
\hline
\end{tabular}

The xiansheng again refers to the Songs of Zhou and the South, but his quotation麟定公族 linding gongzu is not correct, the original text is: 麟之定, 振振公姓lin zhi ding zhen zhen gong xing, the Legge's translation is 'the forehead of the Lin, the noble grandsons of our prince', in A. Shtukin `s translation: 'how noble is kylin's forehead, now the duke has an offspring'. These quotes from Shijing are not only prone with mistakes, they are too fragmentary to understand by a person lacking training in classics, but certainly they provide enough information for the literati. In his comments Tian Ziru also mentions a chapter 'People's wealth' Fumin pian 富民篇from Guanzi 管子, and the Book of Rites Liji 禮記, chapter 'System of ruling' Wangzhi 王制. So, these comments represent a case when auspicious sayings popular among wide public e.g. "precious sons are born in pair' are mentioned together with quotations from the more elevated cultural layer, thus illustrating the ambivalent background of the artist.

\section{Conclusion}

Scholar from Taiwan Yang Yu-jun, who has been doing research of the woodblock prints from the Museum of the History of Religion, argues that popular prints being a field of interaction between the higher and popular culture tend to be misinterpreted by their biased commentators, while the manner of certain pictures bears traces of the 'literati panting' (Yang, 2013; Yang, 2014). Our research brings to light commentary notes and elicits new facets of this interaction. As early as the beginning of the $20^{\text {th }}$ century Alekseev made a correct observation about the role of the literate picture designers as intermediaries between the corpus of Confucian learning (in its basics, though) and mostly illiterate clientele purchasing the woodblock pictures. His diary notes also record difficulties he faced finding mentors who were both literate and able to write detailed commentaries for his collection of nianhua prints, since some xiansheng tended to look down at them. This paper does not focus on pictorial and verbal representations of the interaction between the elite and popular culture seen on the prints themselves, but chooses the notes to display how the commentators' personality and background affected their descriptions. Another unique aspect

\footnotetext{
* The original text in The Book of Songs is麟之趾、振振公子, lin zhi zhi, zhen zhen gong zi, translated by Legge as, 'The feet of the Lin, The noble sons of our prince.' (Chapter Lessons from the States Guofeng 國風, section The Odes of Zhou and the South Zhounan 周南), in the Russian translation by A. Shtukin: 'the feet of the kylin are full of mercy, those are noble sons of a duke'.

${ }^{+}$Commentary says that these phrases compare the noble appearances of the duke`s sons to the mythical animal kylin.
} 
of these notes is a written dialogue between Alekseev and his mentors, which also reveals peculiar differences in logic and perception between the representatives of the two cultures. The paper displays how xiansheng in their commentaries reserve to both popular knowledge in the form of auspicious phrases (e.g. 'let precious sons are born in pair', or 'would you receive a title of a duke upon your wish') and the quotations (often incorrect) from the Confucian classics, Daoist scriptures and literary works.

\section{Acknowledgements}

This publication was generously supported by the Russian State Fund for Humanities (RGNF), project №15-21-10001.

\section{References}

Alekseev, 1958 - Alekseev, V. M. (1958). V Starom Kitae (In old China). Moscow.

Bankovskaya, 2010 - Bankovskaya, M. V. (2010). Alekseev i Kitai. Kniga ob Otze (Alexeev and China. Book about father). Moscow: Vostochnaia literatura RAN.

Johnson et al., 1985 - Johnson, D., Nathan A.J., Rawski E.S. eds. (1985). Popular Culture in Late Imperial China. Berkeley: University of California Press.

Lust, 1996 - Lust, J. (1996). Chinese Popular Prints. Leiden; New York: E.J. Brill.

Marriott, 1955 - Marriott, M. (1955). Little Communities in an Indigenous Civilization. (Village India). American Anthropologist. Vol. 57. №3. pp. 171-222.

Pchelin, Rudova, 2008 - Pchelin N., Rudova M. (2008). Nianhua. Muzei, Spetvypusk (Museums, special issue). Publishing House "Ruda i metally". pp. 85-105.

Rawski, 1979 - Rawski, E. S. (1979). Education and Popular Literacy in Ch'ing China. Ann Arbor: University of Michigan Press.

Riftin, 2009 - Riftin, B. (2009). 李福清. Zhongguo Mubanhua zai Eluosi 中國木版年畫在俄羅 斯 [Chinese woodblock prints in Russia]. Feng Jicai ed., Zhongguo muban nianhua jicheng. Eluosi cangpin juan 中國木版年畫集成. 俄羅斯藏品卷. Full collection of Chinese woodblock prints. Russian collections volume. Beijing: Zhonghua shuju 中華書局, pp. 444- 511.

Rudova, 1960 - Rudova, M. (1960). Kollektsia V. M. Alekseeva (Pamiantniki kultury i iskusstva Kitaia) (Collection of V.M.Alexeev. Cultural and artistic heritage of China). Soobschenia Gos.Ermitazha (Information of the State Hermitage). №19. pp. 38-41.

Rudova, 1961 - Rudova, M. (1961). Sistematizatsia kitaiskih novogodnih narodnyh kartin (nianhua) leningradskih sobranii (Sistematization of the Chinese popular New Year prints (nianhua) from the Leningrad collections). Trudy Gosudarstvennogo Ermitazha (Papers of the State Hermitage). Leningrad. Vol. 5. pp. 286-298.

Rudova, 1988 - Rudova, M. (1988). Kitaiskaia Narodnaia Kartinka (Chinese Popular Prints). Leningrad: Biblioteka Aurory.

Rudova, 2003 - Rudova, M. (2003). ed. Kitaiskaia Narodnaia Kartina Nianhua iz Sobrania Gosudarstvennogo Ermitazha. Katalog vystavki [Chinese popular picture nianhua from the collection of the State hermitage. Exhibition catalogue]. Saint-Petersburg: AO Slavia.

Singer, 1972 - Singer, Milton B. (1972). When a great tradition modernizes: an anthropological approach to Indian civilization. New York: Praeger Publishers.

Szonyi, 2007 - Szonyi, M. (2007). Making Claims about Standardization and Orthopraxy in Late Imperial China Rituals and Cults in the Fuzhou Region in Light of Watson's Theories. Modern China. Vol. 33. №1. pp. 47-71.

Watson, 1993 - Watson, J. (1993). Rites or beliefs? The construction of a unified culture in late imperial China. Lowell Dittmer, Kim, Samuel eds. China's Quest for National Identity. Ithaca, NY: Cornell Univ. Press. pp. 80-103.

Yang, 2013 - Yang, Yu-jun (2013). 楊玉君. Minsuhua de jiedu yu wudu: yi ecang wugui nao pan tu wei li (民俗畫的解讀與誤讀一以俄藏五鬼鬧判圖為例 [The Interpretation and Misinterpretation of Folk Pictures: A Case of the Zhong Kui Pictures Held in Russian Museums] Minsu Quyi民俗曲 藝, Vol. 181. № 9. pp. 223-64 
Yang, 2014 - Yang, Yu-jun (2014). 楊玉君. Ecang qingmo zhongkui tuxiang kaoyi (俄藏清末 鍾道圖象考釋 [Studies on the Late Qing Pictorial Images of Zhong Kui Held in Russia]. Zhongzheng hanxue yanjiu 中正漢學研究. Issue 1 (June). pp. 25-52.

Zang, 1995 - Eluosi Donggong Zang: Zhongguo Nianhua Tesezhan 俄羅斯冬宮館藏: 中國年 畫特色展 [Collection of the Russian Winter Palace: special exhibition of the Chinese nianhua]. Taipei: Guoli lishi bowuguan 國立歷史博物館.

УДК 299.51

\section{Взаимодействие «высокой» и «низкой» культур в позднеимперском Китае: по материалам коллекции китайских народных картин няньхуа из собрания В. Алексеева}

Екатерина Александровна Завидовская а, *, Екатерина Александровна Терюкова b

a Национальный университет Цин Хуа, Тайвань

b Государственный музей истории религии, Российская Федерация

Аннотация. В статье рассматриваются письменные комментарии к китайским народным картинам няньхуа 年畫из коллекции русского синолога В.М. Алексеева (18811951), составленные по его заказу его китайскими помощниками-учителями (сяньшенами 先 生) во время его стажировки в Китае в 1906-1909 гг. Публикуемые в статье рукописные комментарии хранятся в фондах Государственного музея истории религии (СанктПетерубрг) и лишь недавно попали в поле исследования. Они демонстрируют большую или меньшую осведомленность комментаторов в области знания классиков конфуцианства и классической литературы, некоторые из авторов являются представителями профессионального сообщества, занятого производством няньхуа, и отражают хорошее знание ими символических значений представленных на картинах сюжетов и персонажей. В статье все комментарии рассматриваются как результат взаимодействия «высокой» и «низкой», простонародной, культур в Китае, т.е. как комментарии образованных людей составленные по поводу народного искусства. Изучение этих комментариев позволило выявить элементарное, неглубокое знание классических текстов их составителей, чем объясняется не всегда корректное соответствие вопросов, задаваемых В. Алексеевым, и ответов на них.

Ключевые слова: высокая и народная культура, позднеимперский Китай, Василий Алексеев, народная картина, классические каноны.

\footnotetext{
${ }^{*}$ Корреспондирующий автор

Адреса электронной почты: katushaza@yahoo.com (Е.А. Завидовская), eaterioukova@mail.ru (Е.А. Терюкова)
} 